\title{
Pemanfaatan Sistem Informasi Akuntansi Dengan Accurate Online Yang Efektif Dalam Peraturan Work From Home (WFH) di Katering Kino Surakarta
}

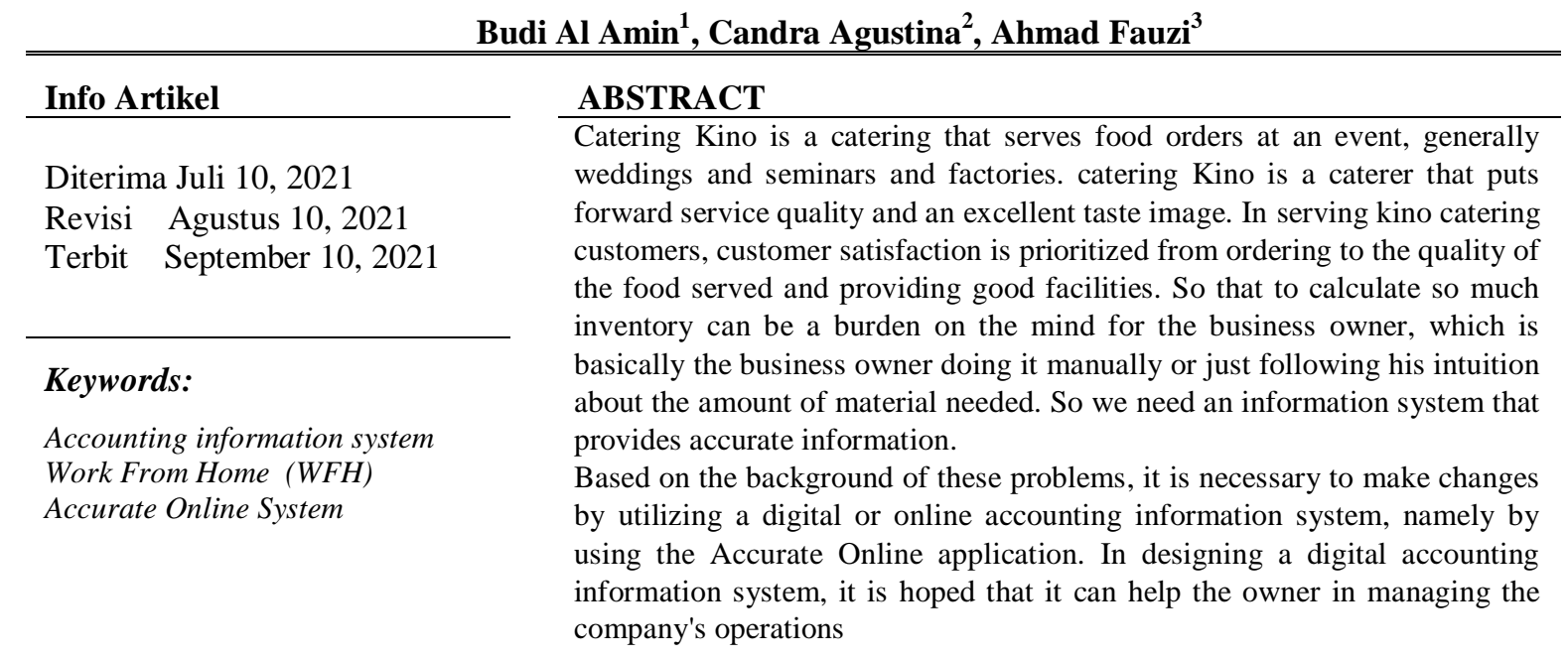

Identitas Penulis:

Budi Al Amin ${ }^{1}$, Candra Agustina ${ }^{2}$, Ahmad Fauzi ${ }^{3}$

Program Studi Sistem Informasi Akuntansi

Universitas Bina Sarana Informatika Surakarta

Jl. Letjen Sutoyo No.43, Cengklik, Nusukan, Kec. Banjarsari Surakarta

E-mail: budi.bdm@bsi.ac.id, candra.caa@bsi.ac.id, ahmad.fzx@bsi.ac.id

\section{PENDAHULUAN}

Perkembangan dunia usaha kecil menengah atau UMKM sedang dalam perubahan menuju digitalisasi administrasi disebabkan pada masa pandemic yang berkepanjangan diharapakan UMKM masih dapat bertahan dan lebih berinovasi dan menyesuaiakan dengan aturan pada masa pandemic berikut ini adalah gambaran usaha kecil menengah dibidang Jasa Katering Kino yang lokasi di Surakarta yang mendapatkan imbas dari masa pandemic dari turunnya order serta syarat mengadakan pesta pernikahan maupun seminar yang harus mengikuti protocol kesehatan disamping itu terdapat beberapa pengurangan karyawan yang tidak terlalu efektif didalam kantor maupun bagian produksi, sehingga pemilik usaha memutar otak untuk bagaimana cara mengelola perusahaan dengan kondisi saat ini dan lebih efektif dalam pengedaliannya. Katering Kino adalah Katering yang melayani pemesanan makanan pada suatu event, umumnya pernikahan. Katering Kimo adalah katering yang mengedepankan kualitas layanan dan citra rasa yang prima. Katering Kino memiliki kekhususan dalam desain tatanan meja dan juga mengangkat cita rasa lokal untuk menjadi jamuan istimewa. Layanan juga bersifat customize, dapat disesuaikan sesuai dengan tema acara dan tamu yang akan dilayani. Tantangan sebuah bisnis katering adalah pengelolaan sumberdaya manusia dan peralatan yang efektif serta efisien. Beberapa masalah yang umum dihadapi oleh bisnis katering adalah bagaimana menangani pemesanan dari calon pelanggan yang ingin mengetahui detil makanan yang tersedia, menu yang dapat dirancang sesuai dengan anggaran, maupun identifikasi dan penelusuran order dari pelanggan tanpa salah maupun dengan kesalahan yang seminimum mungkin. Semua jenis kegiatan transaksi dilakukan pada usaha tersebut masih dilakukan secara manual, seperti pencatatan pemesanan dan pencatatan property. Setiap dilakukan proses transaksi pemesanan, maka akan dilakukan proses pencatatan 
pada buku nota sebagai bukti terjadinya transaksi terhadap konsumen masih secara manual.informasi yang dibutuhkan antar departemen juga masih manual by phone dan nota. Pembuatan order oleh Marketing Juga masih sering terjadi kendala seperti kesalahan dalam menerima order/ ketidak sesuaian, disamping itu konsumen kurang bebas dalam menentukan menu yang sudah ditawarkan, harga yang sudah paket dan promosi yang kurang. Stock persediaan bahan baku digudang belum dikelola denngan baik belum ada kartu stok.

Perhitungan laba rugi yang dilakukan pada usaha masih dilakukan secara manual dan kurang detail, sehingga sulit untuk mengetahui apakah penjualan mengalami keuntungan atau kerugian. Pada masa pandemic yang sulit ini dengan sedikit ada penurunan order terkait dengan aturan pemerintah yang melarang pesta pernikahan sehingga perlu dilakukan inovasi dalam pemasran produk dari catering mulai merambah dengan menyediakan paket box rice dengan menu yang bervariasi yang ditawarkan ke pabrik2 disamping itu tidak semua pegawai catering masuk ke kanror kalau bias dilkerjakan dirumah lebih baik atau work from home sehingga masuknya bergilir dan bergantian dengan mengikuti aturan pemerintah. Dari permasalahan pada Katering Kimo yang telah dijelaskan di atas, solusinya yaitu dibutuhkan sebuah aplikasi sistem informasi akuntansi digital yang bertujuan untuk membantu mempermudah dalam mengolah data-data informasi akuntansi yang berguna untuk usaha. Wawancara dengan pegawai yang menjadi user dari program Accurate online.

\section{METODE}

Di dalam penelitian ini, dibahas pemanfaatan Aplikasi Accurate Online pada transaksi Katering Kino di Surakarta dengan membatasi penulisan pada transaksi-transaksi yang terjadi pada saat melakukan pekerjann dirumah atau Work From Home lalu mengaplikasikan ke dalam aplikasi Accurate Online dari mulai membuat data perusahaan baru, pembuatan akun, pembuatan saldo awal, pengelolahan transaksi seperti adanya pembelian dan penjualan barang secara kredit maupun tunai hingga menyajikan laporan keuangan. Pengolahan transaksi seperti adanya pembelian barang secara kredit maupun tunai.

Tools aplikasi yang digunakan adalah Accurate Online, merupakan sebuah program akuntansi yangbersita digital dengan konektifitas menggunakan jaringan internet dengan basis data menggunakan $\mathrm{O}$ cloud. Program ini dirancang sangat simple dan memudahkan bagi user memahami alur transaksi sesuai dengan bisnis core karena dalamhal ini program ini juga menggunakan bahasa Indonesia atau Bahasa Inggris.Dengan pelatihan secara daring pegawai sudah dapat menjalankan aplikasi sesuai dengan tanggungjawabnya., program ini adalah pengembangan dari program yang sebelumnya accurate 5 yang belum online.

\section{HASIL}

Katering Kino Mencoba untuk menggunakan dan memanfaatkan Aplikasi Akuntansi Dengan berbasis online dan memilih menggunakan program accurate online dengan biaya yang tidak mahal dan biasa diterapkan sesuai dengan bisnis yang berjalan. Berikut ini adalah langkah setup data awal dalam menjalankan program Accurate online yang sangat simple dan mudah dipahami oleh user Membuat Database

Jika Anda sudah selesai membuat akun Accurate Online, langkah selanjutnya adalah membuat database yang akan berisi semua data terkait pembukuan dan transaksi bisnis Anda. Klik tanda tambah untuk membuat database baru seperti gambar dibawah ini : 
Vol. 02, No. 02, September 2021, pp. 23 32

E-ISSN: 2721-7523

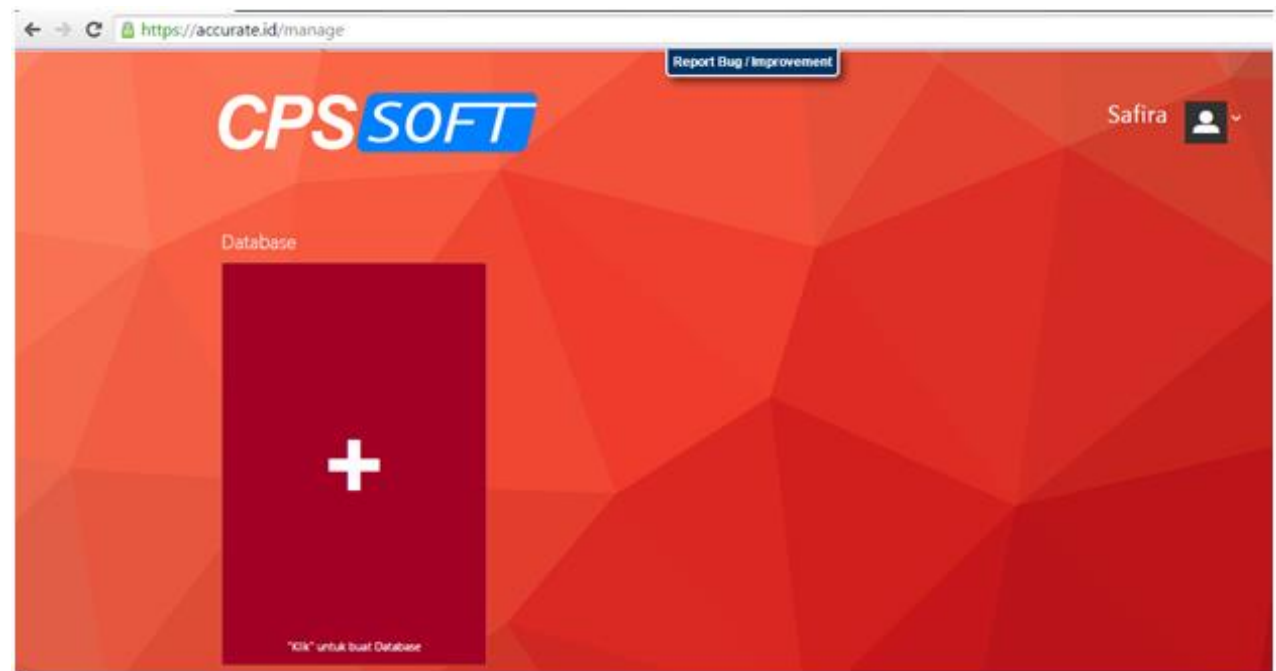

Sumber: Accurate (2020)

\section{Gambar 1 Tampilan Menu Utama Accurate}

Selanjutnya Anda bisa mengisi nama database perusahaan Anda, latar warna yang akan Anda gunakan, dan lgo database. Jika sudah selesai pilih tombol "Simpan"

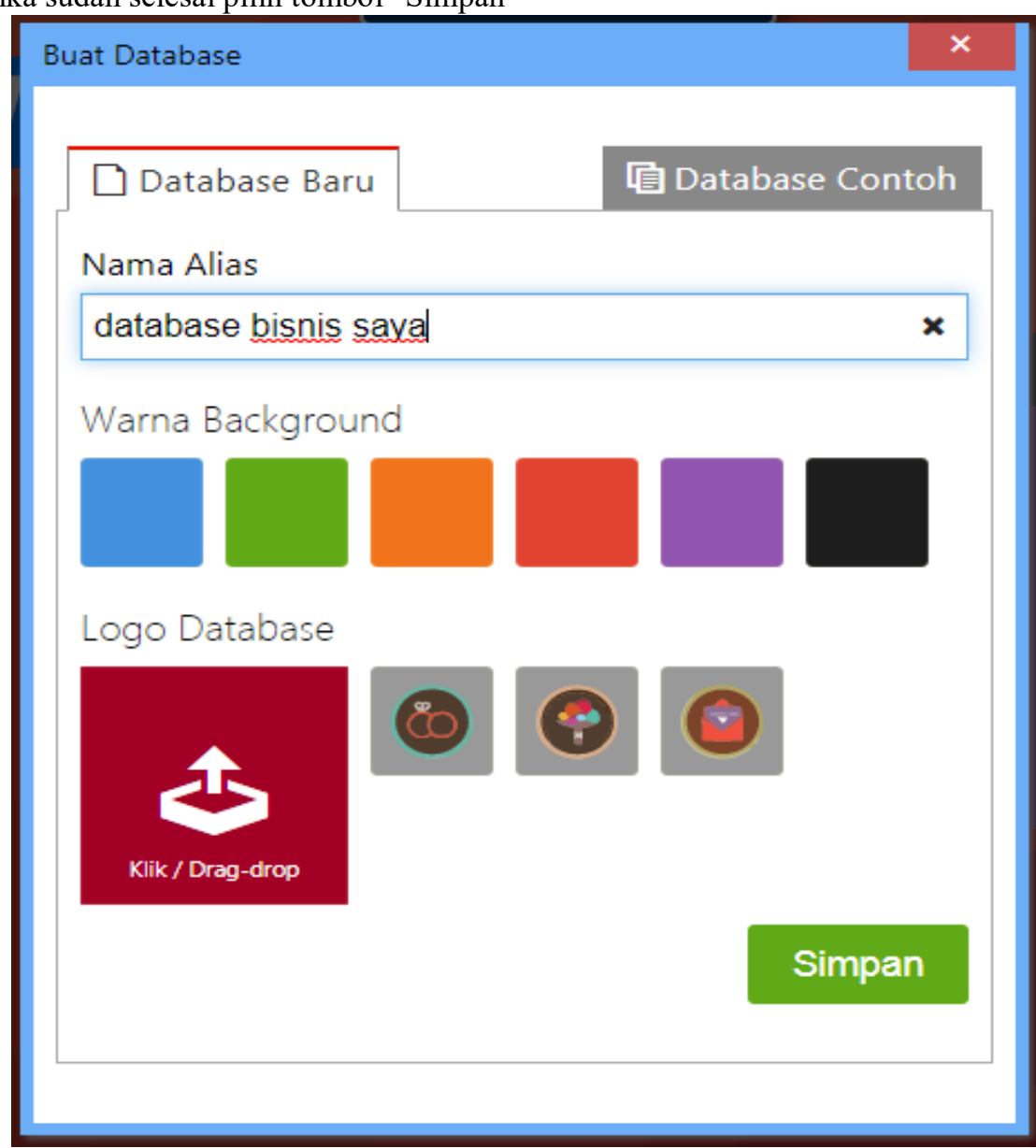

Sumber: Hasil Penelitian (2020)

Gambar 2 Tampilan Menu Pembuatan Database Baru 
Anda sudah berhasil membuat database kosong, langkah selanjutnya adalah mengisi data yang nantinya akan digunakan untuk pencatatan pembukuan pada database ini. Klik database yang telah Anda buat.

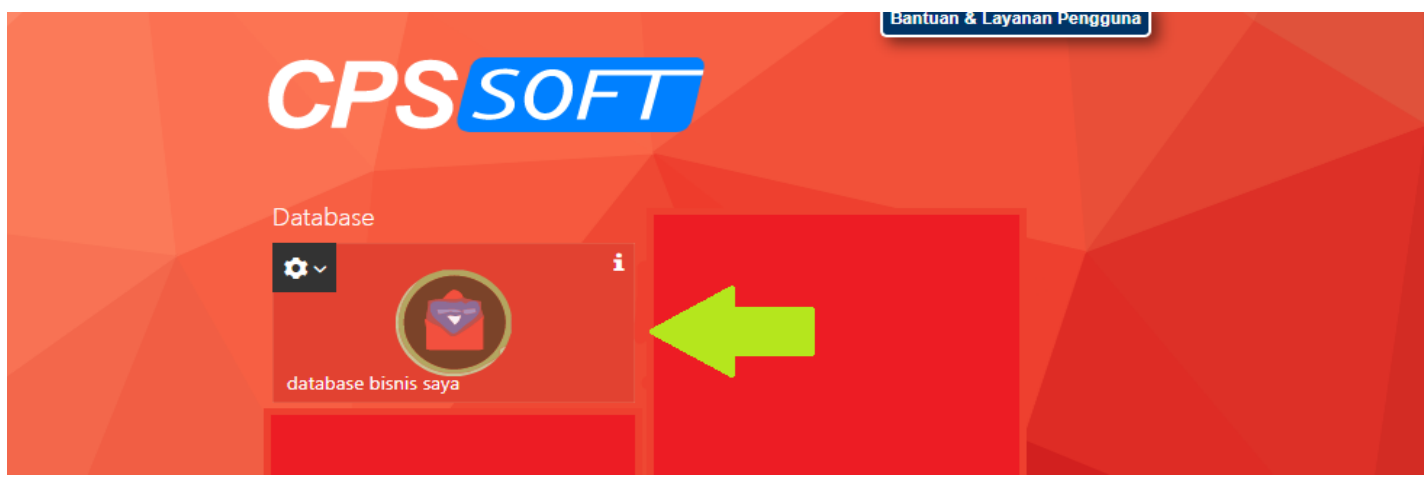

Sumber: Accurate (2020)

\section{Gambar 1 Tampilan Database}

Mengisi Data dan Pengaturan Awal

Setalah Anda mengklik database, Anda akan dibawa pada pengaturan awal. Langkah ini adalah sebagai dasar dalam menentukan seperti apa pembukuan bisnis Anda nantinya berjalan. Tenang saja, ini tidak lebih dari 10 menit.

\section{Info Perusahaan}

Yang pertama harus Anda lengkapi adalah info perusahaan. Isi semua kolom tersebut berdasarkan data sebenarnya, jika sudah pilih lanjut. Lihat contohnya di bawah ini :

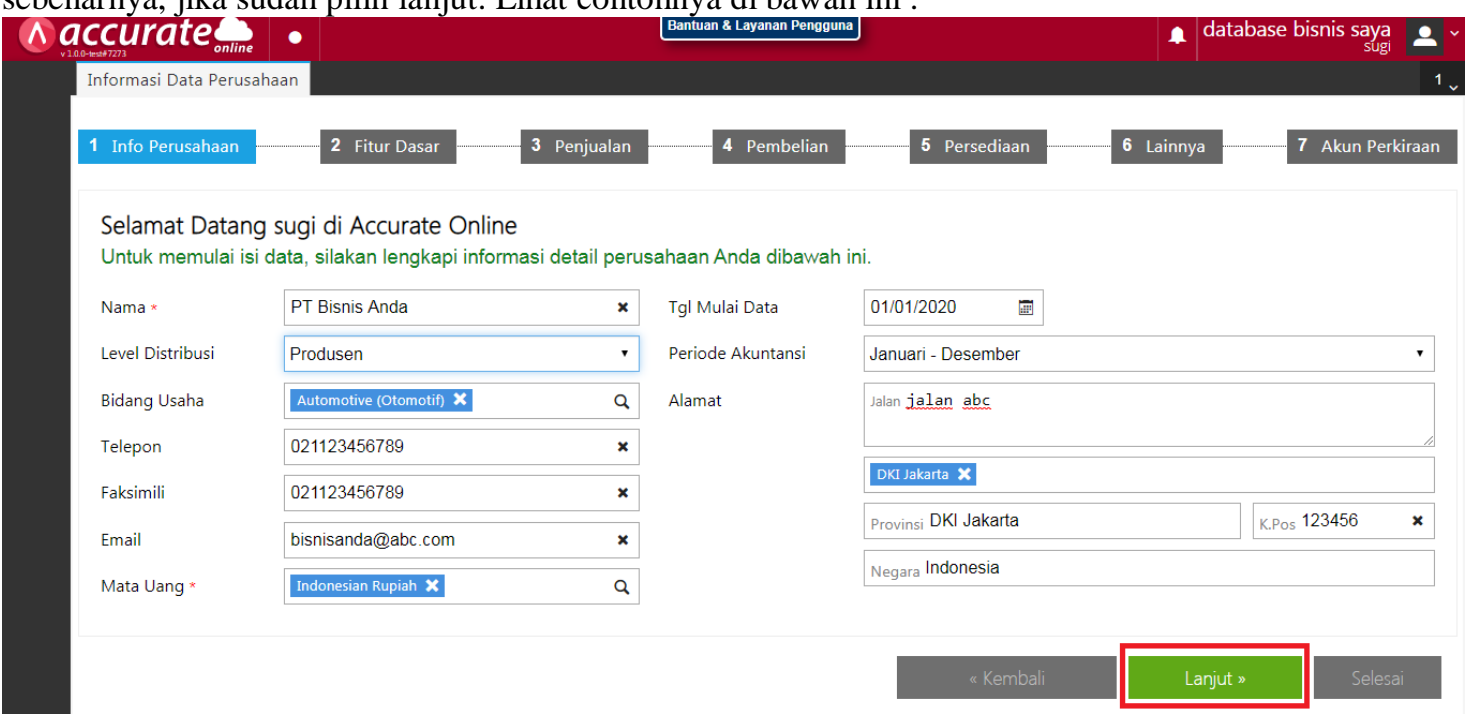

Sumber: Accurate (2020)

\section{Gambar 3 Menu Informasi Data Perusahaan}

Pada contoh di atas, level distribusi perusahaan adalah selaku produsen. Anda bisa memilih level distribusi sesuai dengan bisnis yang Anda jalani yaitu produsen, distributor, atau retailler. Hal ini pun berlaku saat Anda memilih bidang usaha Anda.

\section{Fitur Dasar}

Selanjutnya adalah fitur dasar. Nantinya ini akan menentukan ditur apa saja yang bisa digunakan Anda pada akun Accurate Online Anda, namun jika Anda salah dalam menentukan fitur dasar, atau kebutuhan bisnis Anda telah berubah seiring perkembangan bisnis dan membutuhkan fitur lain, Anda dapat mengubah fitur yang Anda tentukan dikemudian hari dari menu preferensi. 


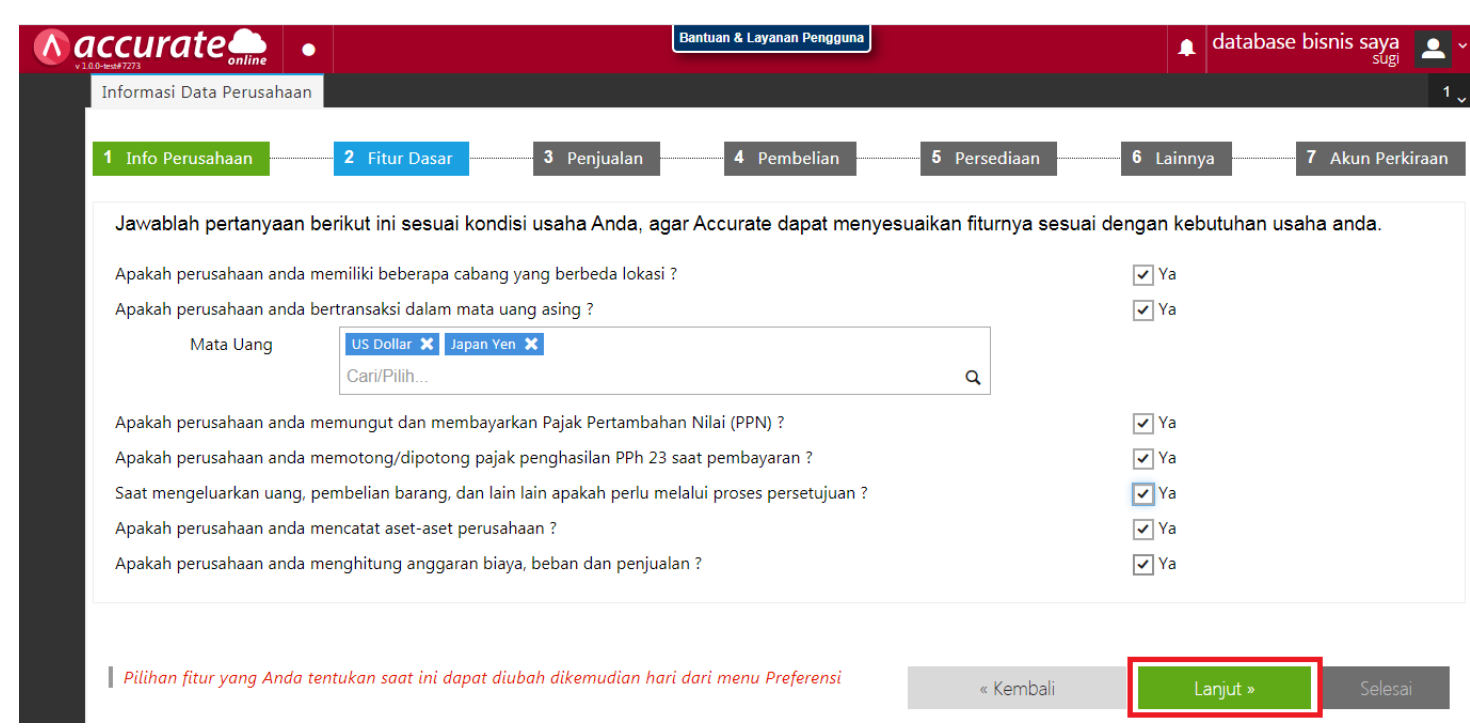

Sumber: Accurate (2020)

\section{Dasar Menu Penjualan}

\section{Gambar 4 Menu Fitur Dasar}

Lalu Anda akan dibawa pada pemilihan kebutuhan Anda pada menu penjualan nantinya. Ini akan menentukan fitur yang bisa Anda gunakan pada menu penjualan di akun Accurate Online Anda.

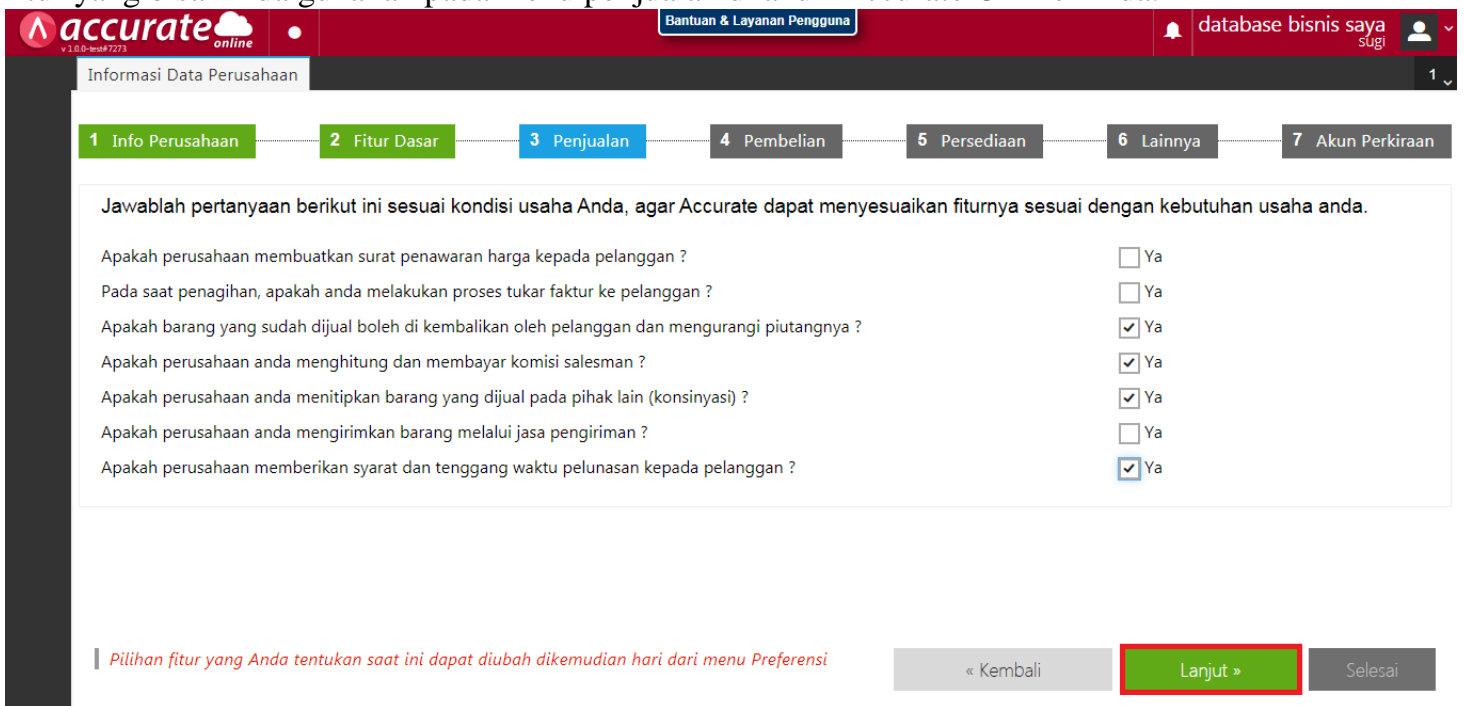

Sumber: Accurate (2020)

4. Dasar Menu Pembelian

\section{Gambar 5 Tampilan Menu Penjualan}

Lalu selanjutnya adalah memilih fitur yang akan Anda dapatkan pada menu pembelian. Sama seperti diatas, pada langkah ini Anda akan diminta untuk mengisi kolom pilihan berdasarkan kebutuhan bisnis Anda sekarang. 


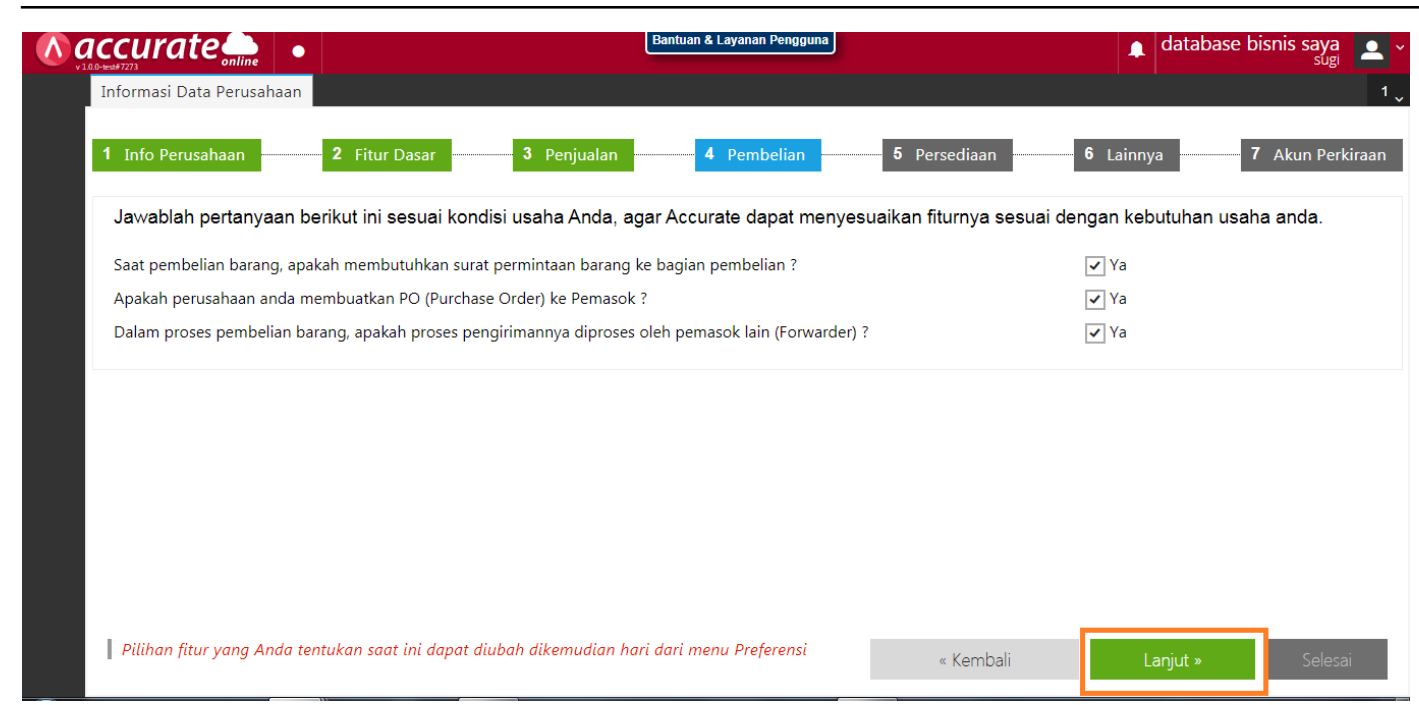

Sumber: Accurate (2020)

\section{Dasar Menu Persediaan}

\section{Gambar 6 Tampilan Menu Pembelian}

Pada poin ini, Anda akan memilih fitur dan metode yang digunakan oleh Anda dalam pengelolaan persediaan. Seperti biasa, pilihlah sesuai kebutuhan bisnis Anda yang sekarang Anda jalani. Accurate Online memiliki 2 metode perhitungan persediaan yaitu FIFO dan Avarage, untuk mengetahui bedanya, Anda bisa membacanya melalui

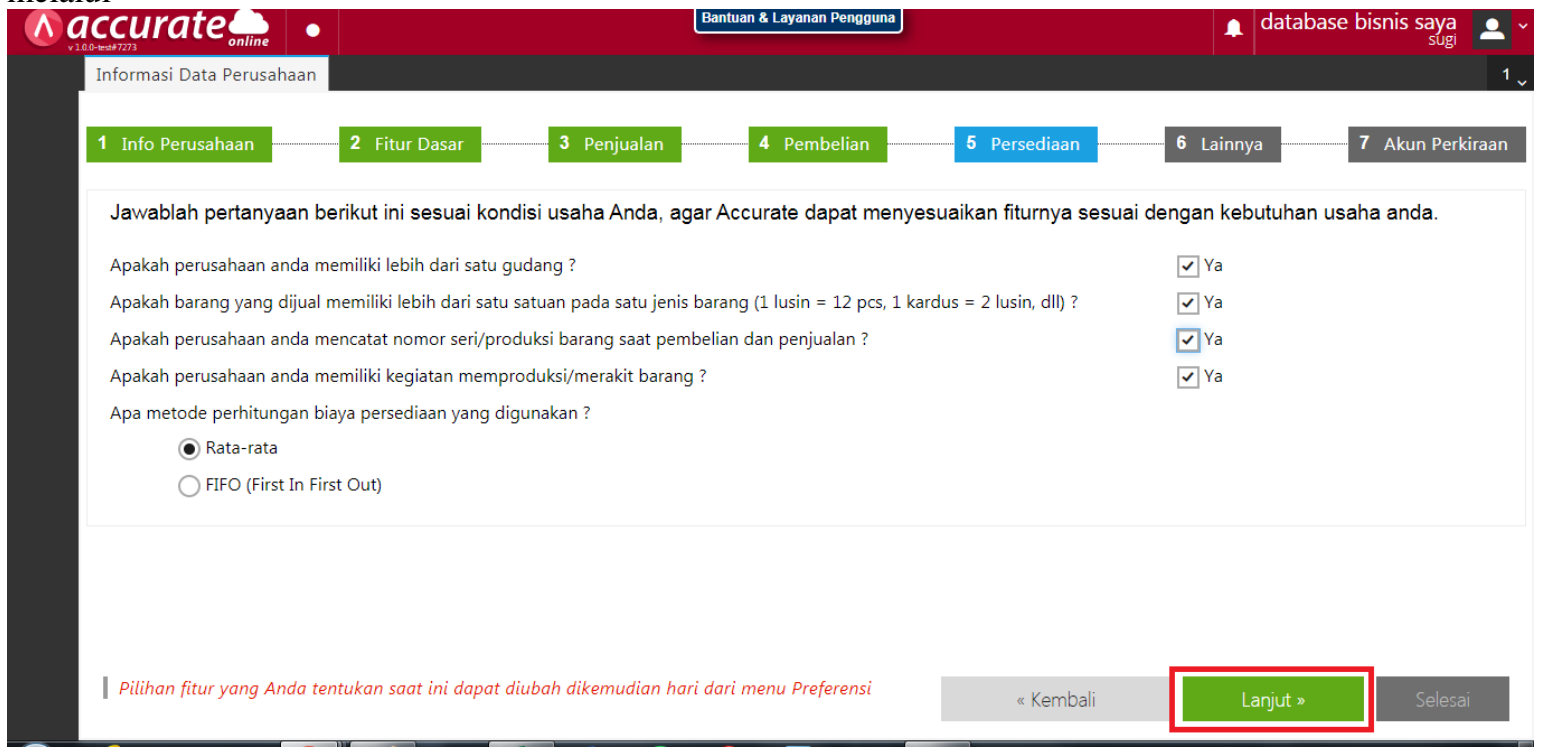

Sumber: Accurate (2020)

\section{Opsi Pencatatan Beban Per Departemen dan Per Proyek}

\section{Gambar 7 Tampilan Menu Persediaan}

Pada langkah ini, Anda bisa memilih untuk mencatat semua beban dengan banyak departemen dan proyek atau tidak. Biasanya ini dipilih jika bisnis Anda sudah berskala menengah ke atas yang memiliki banyak departemen dan menangani banyak proyek dengan anggaran yang berbeda. 


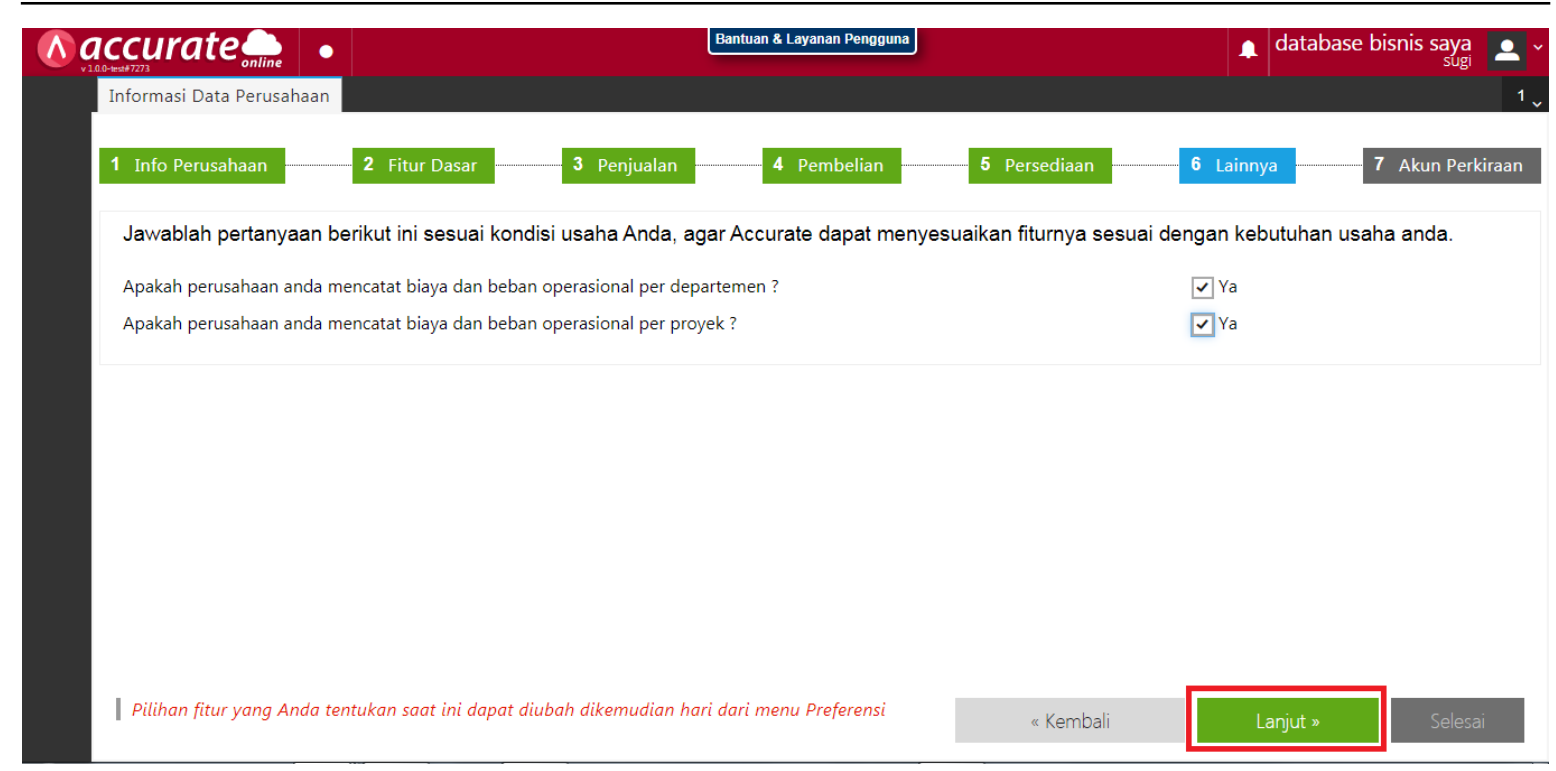

Sumber: Accurate (2020)

\section{Gambar 8 Tampilan Menu Lainnya}

\section{Pengaturan Akun Perkiraan}

Accurate Online membutuhkan akun perkiraan sebagai penampung nilai-nilai kas, pendapatan, persediaan, biaya, beban, dll. Jika anda kurang memahami bagaimana mendefinisikan daftar akun perkiraan untuk perusahaan anda, Accurate dapat membuatkan secara otomatis daftar akun perkiraan yang umum digunakan oleh kebanyakan perusahaan. Jika sudah pilih opsi "Selesai"

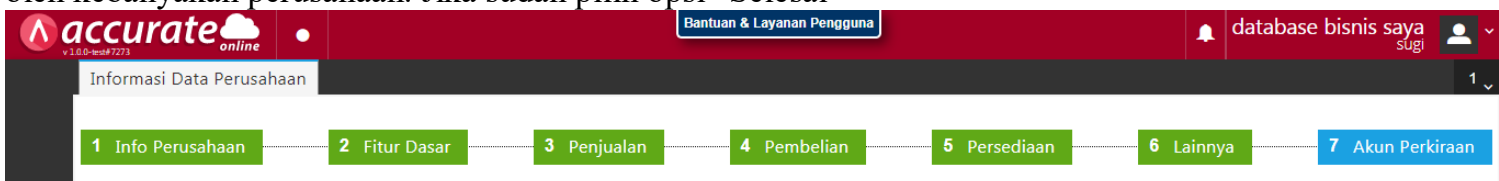

Accurate membutuhkan akun perkiraan sebagai penampung nilai-nilai kas, pendapatan, persediaan, biaya, beban, dll. Jika anda kurang memahami bagaimana mendefinisikan daftar akun perkiraan untuk perusahaan anda, Accurate dapat membuatkan secara otomatis daftar akun perkiraan yang umum digunakan oleh kebanyakan perusahaan

Apakah anda ingin Accurate otomatis membuatkan daftar akun perkiraan ?

Sumber: Accurate (2020)

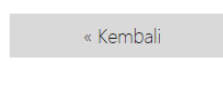

\section{Lanjut »}

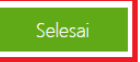

\section{Gambar 9 Tampilan Menu Akun Perkiraan}

Persiapan Data Perusahaan

Setelah Anda berhasil mengisi itu semua, berarti Anda telah mempersiapkan fitur yang dibutuhkan dan sesuai oleh bisnis Anda.

Selanjutnya adalah melakukan persiapan data awal pada perusahaan. Contohnya adalah data pelanggan, stok barang, atau pemasok jika Anda memiliki pemasok. contohnya adalah seperti gambar dibawah ini : 


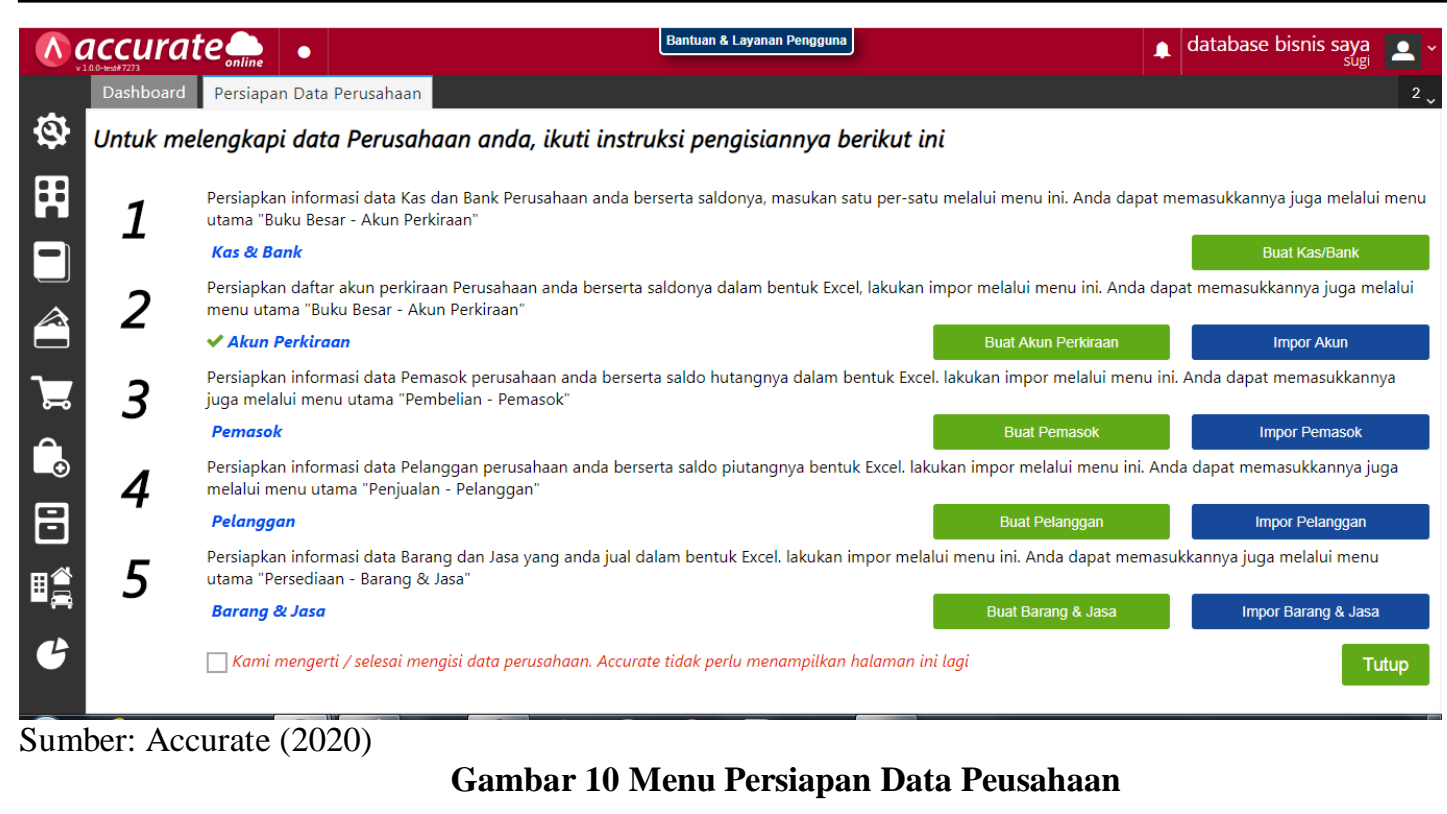

Kas dan Bank

Opsi ini untuk mempersiapkan informasi data kas dan Bank Perusahaan anda berserta saldonya, masukan satu per-satu melalui menu ini. Anda dapat memasukkannya juga melalui menu utama "Buku Besar - Akun Perkiraan"

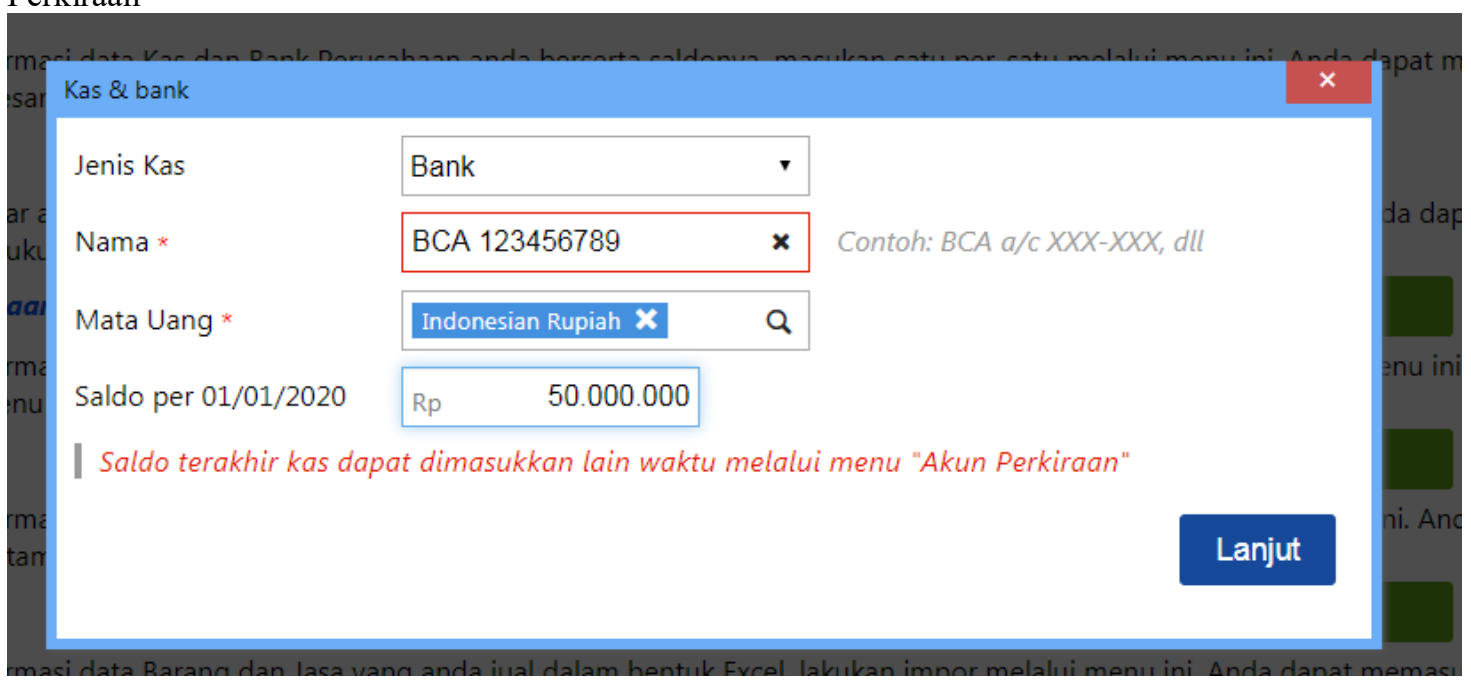

Sumber: Hasil Penelitian (2020)

\section{Gambar 11 Menu Kas \& Bank}

Pemasok, Pelanggan, dan Barang / Jasa

Anda bisa menambah pemasok, pelanggan, dan barang / jasa secara manual dan satu persatu dengan menekan impor "Buat Pemasok", "Buat Pelanggan", dan "Buat Barang \& Jasa" seperti gambar diatas. Atau Anda bisa mengunggah semua data tersebut melalui file excel sesuai format yang Accurate Online tetapkan dengan memilih opsi "Impor Pemasok", "Impor Pelanggan", dan "Impor Barang \& Jasa". 


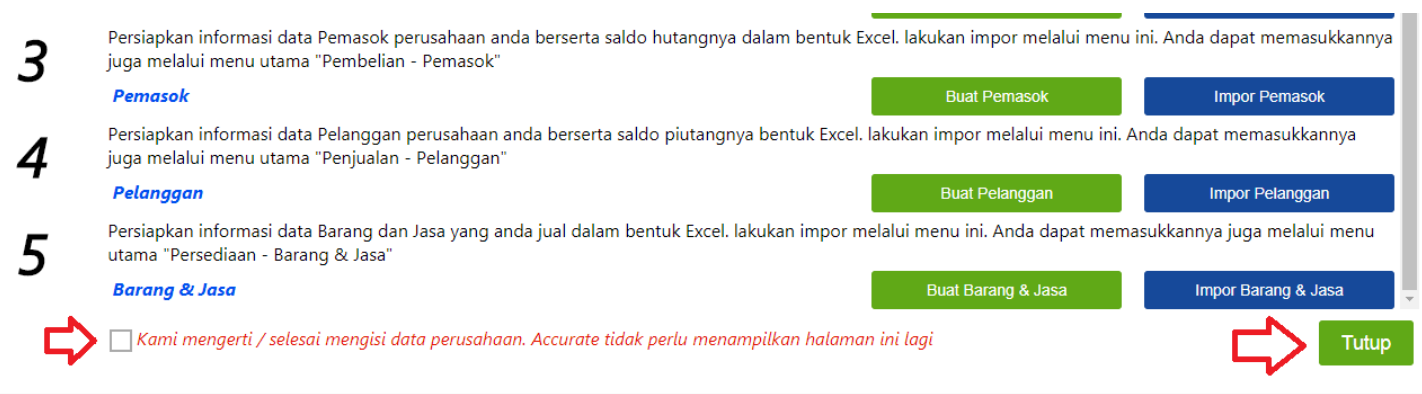

Sumber: Accurate (2020)

Gambar 12 Tampilan Pemasok, Pelanggan, Barang \& Jasa

Sebelum proses impor, persiapkanlah hal hal berikut:

1. Daftar file Pemasok harus dalam bentuk file Microsoft Excel (*.xls, *.xlsx)

2. Accurate menganggap baris pertama data adalah judul kolom, data baris pertama tidak akan di impor

3. Gunakan karakter titik (.) untuk pemisah desimal dan format tipe tanggal $\mathrm{dd} / \mathrm{mm} / \mathrm{yyyy}$ (contoh:

15/04/2014)

4. Untuk data kolom mata uang, isikan sesuai dengan kode mata uang. cth : IDR, USD, SGD

Accurate Online hanya akan memproses 10.000 baris pertama dari file Excel yang diupload

Jika sudah selesai Anda bisa mencentang opsi kami mengerti dan selesai, lalu klik "Tutup", Dan Anda sudah siap untuk mencatat semua transaksi dan melakukan pembukuan bisnis Anda dengan mudah.

Berikut Ini Contoh hasil laporan R/L yang dihasilkan dalam aplikasi Accurate Online

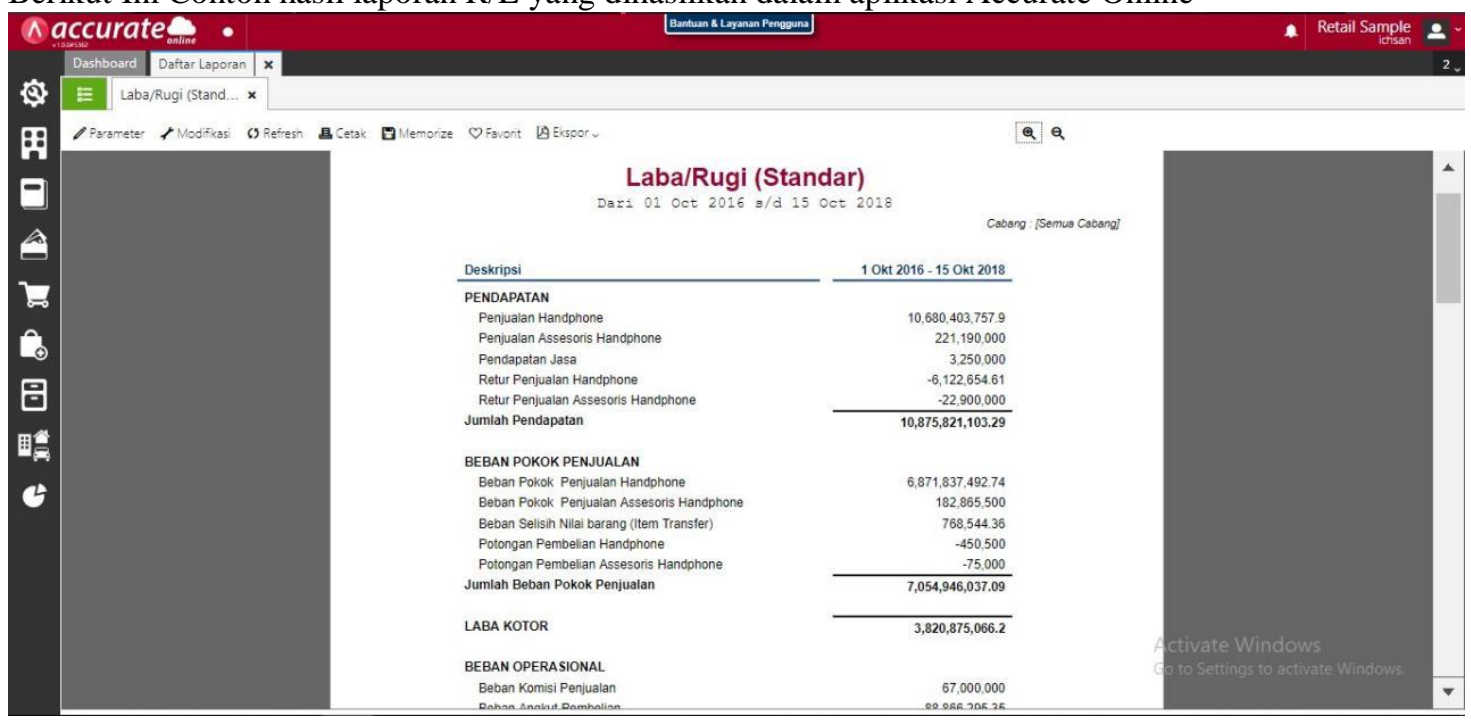

Sumber: Hasil Penelitian (2020)

\section{Gambar 13 Tampilan Laporan}

Berikut Contoh Balance Sheet Dalam Accurate online 


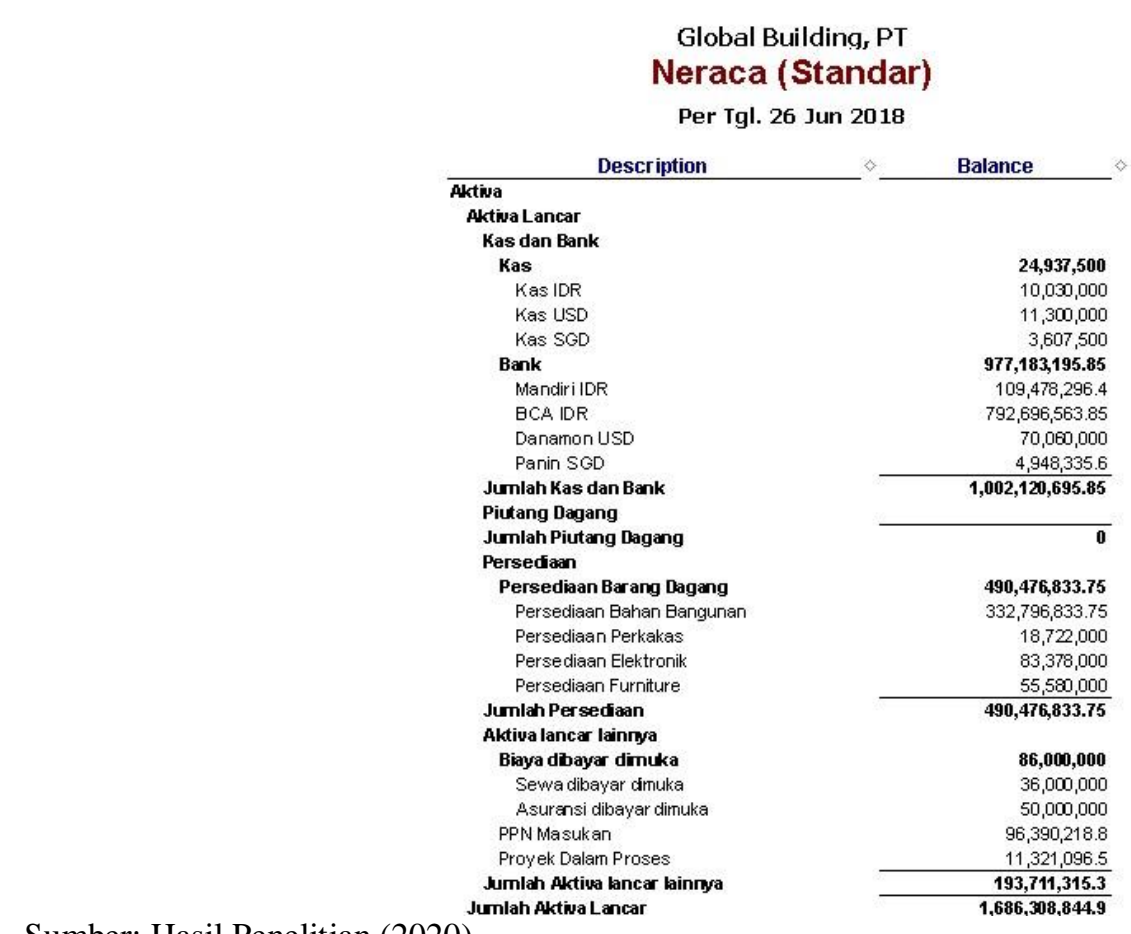

Sumber: Hasil Penelitian (2020)

\section{Gambar 14 Tampilan Neraca}

\section{KESIMPULAN}

Katering Kino adalah sebuah UMKM yang bergerak dibidang jasa menyediakan perlatan pesta pernikahan dan menu hidangan makanan yang akan disajikan selain itu juga melayani pesenan paket nasi box untuk pabrik atau perusahaan sesuai dengan peesanan dan saat in merambah kedalam snack dan café $\mathrm{n}$ restouran. Namun dalam proses penginputan transaksi hingga pembuatan laporan Kino katering masih menggunakan sistem manual dan belum terkomputerisasi dan pada saat kondisi pandemic dengan bekerja dari rumah sebagain pegawai yang membuat semua yang dapat di kerjakan melalui online. Berdasarkan tinjauan bab-bab sebelumnya, maka dapat ditarik kesimpulan bahwa Penggunakan accurate online sangat membantu proses transaksi serta merekam semua kegitatan operasional perusahaan melalui system terintegrasi online. Sistem Accurate online mempermudah dan efektif selain harga yang terjangkau dapat melihat laporan kapan pun dan dimanapun dengan melalui jaringan internet dan langsung melakukan tindakan atas kesalahan atau kecurangan dapat diketahui dengan cepat.

\section{UCAPAN TERIMA KASIH}

Terima kasih kepada Katering Kino Surakarta yang telah bersedia memberikan data dan menerima pengajuan riset untuk aplikasi Accurate Online. Terima kasih pula kepada jajaran civitas akademika Universitas Bina Sarana Informatika serta redaksi Justian dalam penerbitan artikel ini.

\section{REFERENSI (10 PT)}

Referensi dapat berupa artikel nasional ataupun internasional. Semua referensi harus yang terbaru minimum 5 tahun terakhir. Referensi dituliskan dengan nama belakang penulis atau nama institusi dan disusun sesuai alfabet. Seperti contoh berikut

[1] Ikatan Akuntan Indonesia. 2017. Standar Akuntansi Keuangan, Penerbit Salemba Empat, Jakarta.

[2] Modul Accurate Online (https://www.accuratecenter.com/2018/04/25/1138/)

[3] Mulyadi, (2016) Sistem Informasi Akuntansi 